\title{
Isotopic geochronology of granitic rocks from the Central Iberian Zone: comparison of methodologies
}

\section{Geocronología isotópica de rocas graníticas de la Zona Centro-Ibérica: comparación de metodologías}

\author{
I.M.H.R. Antunes ${ }^{1 *}$, A.M.R. Neiva ${ }^{2 \star}$, M.M.V.G. Silva ${ }^{2 *}$
}

\begin{abstract}
Five granitic rocks, concentrically disposed from core to rim, were distinguished in the Castelo Branco pluton. U-Pb-Th electron microprobe monazite ages from granitic rocks are similar and ranging between 297-303 Ma. The granitic rocks from Castelo Branco pluton are $310 \pm 1 \mathrm{Ma}$ old, obtained by U-Pb (ID-TIMS) in separated zircon and monazite crystals, indicating a similar emplacement age for all granitic rocks of the pluton. Initial ${ }^{87} \mathrm{Sr} /{ }^{86} \mathrm{Sr}$ isotopic ratios and $\varepsilon \mathrm{Nd}_{310}$ and $\delta^{18} \mathrm{O}$ values suggest three distinct pulses of granitic magma and that they are derived from partial melting of heterogeneous metasedimentary materials. The other granitic rocks are related by magmatic differentiation and show small variations in $\left({ }^{87} \mathrm{Sr} /{ }^{86} \mathrm{Sr}\right)_{310}, \varepsilon \mathrm{Nd}_{310}$ and $\delta^{18} \mathrm{O}$. The granitic pluton of Castelo Branco shows a rare reverse zoning.
\end{abstract}

Key words: geochronology, zircon, monazite, U-Pb, U-Pb-Th, Sr-Nd, $\delta^{18} \mathrm{O}$, Castelo Branco pluton, Portugal.

\section{RESUMEN}

En el plutón de Castelo Branco, se distinguen cinco granitoides, dispuestos concéntricamente de núcleo a borde del plutón. Las edades U-Pb-Th obtenidas en cristales de monacita por microsonda electrónica en estos granitoides son similares entre sí y varían entre 297 y $303 \mathrm{Ma}$. Los resultados de datación por U-Pb (ID-TIMS) en cristales de circón y de monacita de los tres granitos seleccionados, indican una edad de implantación de $310 \pm 1$ Ma y que son rocas emplazadas simultáneamente. Las relaciones isotópicas iniciales de ${ }^{87} \mathrm{Sr} /{ }^{86} \mathrm{Sr}$ y los valores de $\varepsilon \mathrm{Nd}_{310}$ y $\delta^{18} \mathrm{O}$ de los tres pulsos magmáticos son característicos de granitos resultantes de anatexia cortical a partir de rocas metasedimentarias heterogéneas. En la secuencia de diferenciación magmática, las rocas graníticas presentan pequeñas variaciones en $\left({ }^{87} \mathrm{Sr} /{ }^{86} \mathrm{Sr}\right)_{310}, \varepsilon \mathrm{Nd}_{310}$ y $\delta^{18} \mathrm{O}$. El plutón de Castelo Branco presenta un zonado inverso poco frecuente.

Palabras clave: geocronología, circón, monazita, U-Pb, U-Pb-Th, Sr- $\mathrm{Nd}, \delta^{18} \mathrm{O}$, Castelo Branco plutón, Portugal.

\section{Introduction}

The emplacement age of granitic rocks can be obtained using recent analytical techniques of high precision. This allows the identification of important geologic episodes and constitutes an important component in the study of the evolution of orogenic processes and crustal materials. U-Pb-Th age determination from electron microprobe geochemical analyses of monazites is a relatively recent techni- que with relevant application on the geochronology of magmatic episodes (Montel et al., 1996). This is a fast and cost-effective methodology, with good resolution, being able to date crystals with $5 \mu \mathrm{m}$ diameter and allowing the study of heterogeneities inside of the same crystal. Minerals are not destructed and the textural relationship of the sample is preserved. The main disadvantage can be related to the lesser precision and minor sensitivity presented by this methodology. Therefore, U-Pb-Th monazite

\footnotetext{
1 Polytechnic Institute of Castelo Branco. Portugal. Email: imantunes@esa.ipcb.pt

2 Department of Earth Sciences. University of Coimbra. Portugal. Email: neiva@dct.uc.pt; mmvsilva@ dct.uc.pt

* Geosciences centre. University of Coimbra. Portugal.
} 
datation can be considered as a first approach to relative information on the age of a rock.

Associated to the necessity of a more accurate and precise analytical techniques, the U-Pb isotopic data of zircon and monazite crystals by ID-TIMS (Isotope Dilution Thermal Ionization Mass Spectrometry) became more usual. In this methodology, the radiogenic $\mathrm{Pb}\left({ }^{207} \mathrm{~Pb}\right.$ and $\left.{ }^{206} \mathrm{~Pb}\right)$, produced by $\mathrm{U}$ isotopic decay, allows to get two independent ages and a third one, not independent, from the isotopic ${ }^{207} \mathrm{~Pb} /{ }^{235} \mathrm{U}$ and ${ }^{206} \mathrm{~Pb} /{ }^{238} \mathrm{U}$ ratios, and corresponding to the ${ }^{207} \mathrm{~Pb} /{ }^{206} \mathrm{~Pb}$ ratio (Rollinson, 1993). These three different ages obtained using the same mineral, confers a high validity to the U-Pb system. In $\mathrm{U}$-enriched and $\mathrm{Pb}$-poor minerals, like zircon and monazite, the amount of initial common $\mathrm{Pb}$ is insignificant relatively to the radiogenic $\mathrm{Pb}$, which supports the application to these minerals.

Strontium and Nd occur in different amounts in the rocks, occurring as trace elements, and dispersed in $\mathrm{SiO}_{2}$-enriched rocks. $\mathrm{Rb}$ - $\mathrm{Sr}$ datation method is applied in the geochronology of granitic rocks. $\mathrm{Rb}-\mathrm{Sr}$ and $\mathrm{Sm}-\mathrm{Nd}$ isotopic data are important geochronological indicators. Initial ${ }^{87} \mathrm{Sr} /{ }^{86} \mathrm{Sr}$ and $\varepsilon \mathrm{Nd}_{\mathrm{T}}$ isotopic magma ratios are characteristic of the magma sources and will remain constant during fractional crystallization processes (Rollinson, 1993).

Whole-rock oxygen isotopic data $\left(\delta^{18} \mathrm{O}\right)$ provides important information relative to the conditions of origin and emplacement of rocks. These data have been particularly used together with geochemical and petrogenetic studies on the magmatic identification and characterization processes.

The Castelo Branco pluton consists of five concentrically zoned peraluminous granitic rocks. The aim of this work is to present and to interpret the different isotopic data (U-Pb-Th; U-Pb; $\mathrm{Rb}-\mathrm{Sr}, \mathrm{Sm}-\mathrm{Nd}$ and $\delta^{18} \mathrm{O}$ ) obtained in the granitic rocks of Castelo Branco pluton. These data will be used to infer the emplacement age of the pluton as well as information on its source.

\section{Geological setting}

The Central Iberian Zone (CIZ) is located at the central part of the Iberian Massif. This zone contains Pre-Cambrian to Lower Palaeozoic rocks and two different domains can be identified: The Ollo de Sapo formation and the Schist-Metagraywacke Complex (CXG) (Martínez Catalán et al., 2004). The Castelo Branco pluton intruded the Cambrian

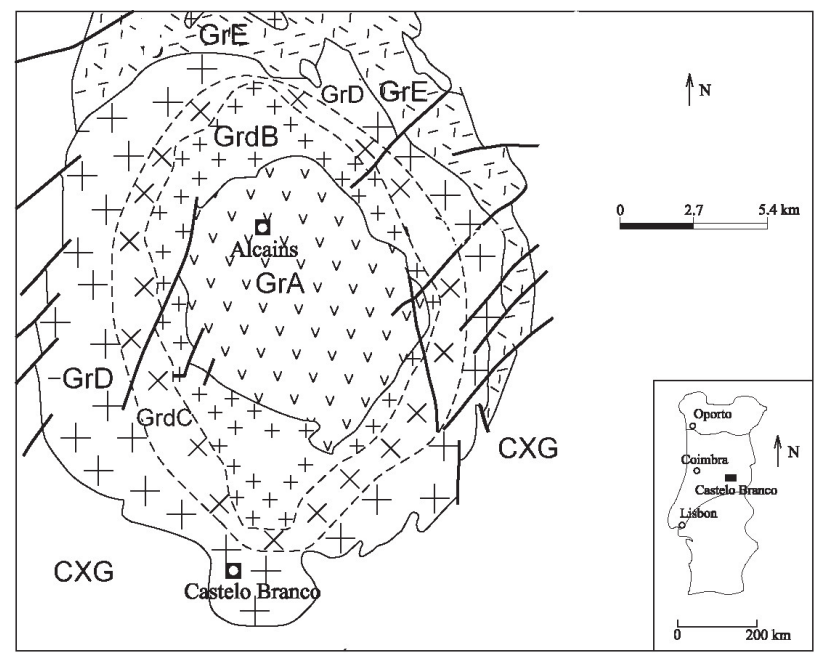

Fig. 1.-Geological map of the Castelo Branco pluton (adaptated from Antunes et al., 2008). CXG-Schist-metagraywacke complex; GrA: medium- to fine-grained muscovite>biotite granite; GrdB: medium- to fine-grained slightly porphyritic biotite>muscovite granodiorite; GrdC: medium- to coarse-grained porphyritic biotite>muscovite granodiorite; GrD: medium- to coarse-grained porphyritic biotite-muscovite granite; GrE: coarse-grained muscovite>biotite granite.

schist-metagraywacke complex, which consists of alternating metapelites and metagraywackes with metaconglomerate and marble intercalations.

Several classifications have been presented for the granitoid rocks of the CIZ. The CIZ granitoids have been emplaced mainly during and after the ductile deformation phase D3 of Namurian-Westphalian age (Ferreira et al., 1987). They are classified according to their emplacement ages as synD3, late-D3, late- to post-D3 and post-D3 (e.g., Neiva \& Gomes, 2001; Dias et al., 2002; Azevedo et al., 2005).

The Castelo Branco pluton is exposed over an area of $390 \mathrm{~km}^{2}$ and consists of five concentric latetectonic Variscan granitic rocks, with an age of $310 \pm 1 \mathrm{Ma}$ and presenting synchronism of installation (Fig. 1).

A medium- to fine-grained muscovite $>$ biotite granite $(\mathrm{GrA})$ occupies the pluton's core and is the oldest one. Granite GrA is surrounded by a medium- to fine-grained slightly porphyritic biotite $>$ muscovite granodiorite $(\mathrm{GrdB})$. The contact between granite GrA and granodiorite GrdB is sharp. The amount of feldspar phenocrysts increases towards the porphyritic biotite $>$ muscovite granodiorite (GrdC). The medium- to coarse-grained granodiorite $\mathrm{GrdC}$ encircles gradually the granodiorite $\mathrm{GrdB}$, grading to the medium- to coarse-grained 
porphyritic biotite-muscovite granite $(\mathrm{GrD})$, which contains equal amounts of biotite and muscovite (Fig. 1). A coarse-grained muscovite $>$ biotite granite $(\mathrm{GrE})$ occupies the periphery of the pluton in the sector from $\mathrm{N}$ to $\mathrm{E}$ (Fig. 1). The contact between granites GrD and GrE is also sharp, but the two granites are usually altered at this contact. The pluton produced mica schists in the outer zone and a pelitic hornfels in the inner zone of the contact metamorphic aureole, particularly on the southern and eastern zones of the pluton.

\section{Analytical methods}

The U-Pb-Th monazite individual ages are calculated from the $\mathrm{U}, \mathrm{Pb}$ and $\mathrm{Th}$ monazite concentrations obtained by electron microprobe on thin sections. This age can be considered valid if, at the time of crystallization, the $\mathrm{Pb}$ is practically inexistent and losses of $\mathrm{Pb}$, Th and $\mathrm{U}$ had not occurred. The U-Pb-Th determinations on monazites were performed on a Cameca SX100 electron microprobe at the Laboratoire Magmas et Volcans of the University of Blaise Pascal, Clermont-Ferrand (France). Analytical conditions included an accelerating voltage of $15 \mathrm{kV}$ and a beam current of $150 \mathrm{nA}$. Standards used included $\mathrm{UO}_{2}(\mathrm{U} \mathrm{M} \alpha), \mathrm{ThO}_{2}$ ( Th $\mathrm{M} \alpha)$, apatite $(\mathrm{Ca} \mathrm{K} \alpha, \mathrm{P} \mathrm{K} \alpha)$, zircon $(\mathrm{Si} \mathrm{K} \alpha)$ and synthetic phosphates (Y L $\alpha$, La L $\alpha$, Ce $L \alpha, \operatorname{Pr} L \alpha$, $\mathrm{Nd} \operatorname{L} \alpha, \operatorname{Sm} \mathrm{L} \alpha, \mathrm{Gd} \operatorname{L} \alpha)$. The theoretical basis and associated statistical treatment of data follow the analytical procedure detailed by Montel et al. (1996). A least-square modelling approach was applied to the ages of the crystals and its quality is assessed from the mean square of weighted deviates (MSWD).

$\mathrm{U}-\mathrm{Pb}$ isotopic data were determined using zircon and monazite separated crystals from selected representative granitic rocks of Castelo Branco pluton. Zircon and monazite separation was carried out by a combination of magnetic separation and flotation in heavy liquids. The $\mathrm{U}-\mathrm{Pb}$ isotopic results for zircon and monazite were obtained by isotope dilution thermal ionization mass spectrometry (TIMS) using a Finnigan-Mat 262 spectrometer at the Department of Geosciences, University of Oslo, Norway, following the standard procedure of Krogh (1973) with the adaptations described by Corfu (2004).

The $\mathrm{Sr}$ and $\mathrm{Nd}$ isotope analyses were obtained at the Centro de Instrumentación Científica of the University of Granada, Spain. Samples were diges- ted using ultra-clean reagents and analyzed by TIMS in a Finnigan Mat 262 spectrometer, after chromatographic separation with ion-exchange resins. Normalization values were ${ }^{86} \mathrm{Sr} /{ }^{88} \mathrm{Sr}=$ 0.1194 and ${ }^{146} \mathrm{Nd} /{ }^{144} \mathrm{Nd}=0.7219$ and the blanks were 0.6 and 0.09 nanograms for $\mathrm{Sr}$ and $\mathrm{Nd}$, respectively. The standards yields values of ${ }^{87} \mathrm{Sr} /{ }^{86} \mathrm{Sr}=$ $0.710252 \pm 0.000021(2 \sigma)$ NBS 987 and ${ }^{143} \mathrm{Nd} /{ }^{144} \mathrm{Nd}=0.511844 \pm 0.000010(2 \sigma)$ La Jolla. ${ }^{87} \mathrm{Rb} /{ }^{86} \mathrm{Sr}$ and ${ }^{147} \mathrm{Sm} /{ }^{144} \mathrm{Nd}$ were determined by ICPMS following the method developed by Montero \& Bea (1998), with a precision better than $\pm 1.2 \%$ and $0.9 \%(2 \sigma)$, respectively.

Oxygen isotope analyses of whole-rock samples were carried out at the Department of Earth Sciences, University of Western Ontario, Canada, using a conventional extraction line and employing chlorine trifluoride as reagent. This methodology has a precision of $\pm 0.2 \%$ and the used standards include quartz and laboratory $\mathrm{CO}_{2}$.

\section{Isotope geochemistry}

To compare different isotopic data and associated emplacement ages for the granitic rocks of Castelo Branco pluton, three different geochronological techniques were used. It will be also presented the whole-rock $\mathrm{Rb}-\mathrm{Sr}, \mathrm{Sm}-\mathrm{Nd}$ and $\delta^{18} \mathrm{O}$ isotopic ratios from granitic rocks to characterize the magmatic sources.

\section{U-Th-Pb on monazite}

Electron microprobe $\mathrm{U}-\mathrm{Th}-\mathrm{Pb}$ isotopic data on monazite, considers that monazite contains small amounts of common $\mathrm{Pb}$, resulting from $\mathrm{Th}$ and $\mathrm{U}$ isotopic decay. Th and $U$ enrichment of monazite promotes a radiogenic $\mathrm{Pb}$ accumulation on the mineral structure, remaining in precise amounts during less than $100 \mathrm{Ma}$ (Montel et al., 1996).

Monazites in all granitic rocks of the Castelo Branco pluton were dated by EPMA (Table 1). Those in samples $\mathrm{GrA}, \mathrm{GrdB}, \mathrm{GrdC}$ and $\mathrm{GrE}$ yield average $\mathrm{U}-\mathrm{Th}-\mathrm{Pb}$ ages of $303 \mathrm{Ma}$ to $301 \mathrm{Ma}$. U-Pb-Th monazite ages from granite $\mathrm{GrD}$ is somewhat lower at $297 \pm 3 \mathrm{Ma}$ (Table 1). However, the granitic rocks obtained ages are similar and consistently within the analytical error (Table 1).

The highest MSWD values obtained for GrD and GrE granites can be associated with the number of 
Table 1.-U-Pb-Th monazite ages of granitic rocks from Castelo Branco pluton (central Portugal)

\begin{tabular}{lccc}
\hline & T (Ma) & MSWD & N \\
\hline GrA & $303 \pm 3 \mathrm{Ma}$ & 9 & 31 \\
GrdB & $301 \pm 4 \mathrm{Ma}$ & 2 & 38 \\
GrdC & $301 \pm 4 \mathrm{Ma}$ & 3 & 32 \\
GrD & $297 \pm 3 \mathrm{Ma}$ & 35 & 45 \\
GrE & $301 \pm 3 \mathrm{Ma}$ & 14 & 49 \\
\hline
\end{tabular}

GrA: muscovite > biotite granite.

GrdB: slightly porphyritic biotite $>$ muscovite granodiorite.

GrdC: porphyritic biotite > muscovite granodiorite.

GrD: biotite-muscovite granite.

GrE: muscovite > biotite granite.

$\mathrm{N}$ : number of analyses.

points and some scatter, which may reflect some initial $\mathrm{Pb}$ associated with unresolved geological complexity or due to alteration processes.

\section{$U-P b$ on zircon and monazite}

$\mathrm{U}-\mathrm{Pb}$ isotopic analyses were carried out on separated zircon and monazite crystals from three samples representing the GrA, GrdB and GrE of Castelo Branco pluton, using the ID-TIMS method (Table 2). Granodiorite $\mathrm{GrdC}$ and granite $\mathrm{GrD}$ were not considered because field relationships and geochemical characteristics suggest that they are related to granodiorite GrdB by a fractional crystallization process (Antunes et al., 2008). U-Pb zircon and monazite ages inside the granitic rocks are consistent and similar (Table 2).
The zircon crystals from granite GrA are concordant, defining a good alignment $(\mathrm{MSWD}=1.11$ ) and yielding an emplacement age of $309.9 \pm 1.1 \mathrm{Ma}$. The more concordant zircon yields a ${ }^{207} \mathrm{~Pb} /{ }^{206} \mathrm{~Pb}$ age of $309.9 \pm 1$ Ma with a discordance of $1.1 \%$ (Table 2).

The monazite crystals plot slightly reversely discordant, a fact commonly linked to Palaeozoic geological processes. The ${ }^{207} \mathrm{~Pb} /{ }^{235} \mathrm{U}$ ratio is not affected by this disequilibrium effect and can be used as the closest estimate for the age of the monazite (Table 2).

The zircon analyses for a sample of granodiorite GrdB plot on or close to the Concordia curve. However, one zircon crystal suggests minor inheritance and the age of $310.1 \pm 0.8 \mathrm{Ma}$ from the more concordant zircon should be considered (Table 2). The monazite and zircon crystals yields a similar age (Table 2).

The zircon analyses from granite GrE defines a discordia line which yields a lower intersect age of $309.1 \pm 0.6 \mathrm{Ma}$ and an upper intersect age of about 1,000 Ma. The emplacement age is similar to the ${ }^{207} \mathrm{~Pb} /{ }^{206} \mathrm{~Pb}$ age for the more concordant zircon crystal (Table 2). The monazite analyses scatter towards the Concordia curve, however the more concordant monazite yields and age of $309.7 \pm 0.4 \mathrm{Ma}$, similar to the concordant zircon ages (Table 2).

Considering the U-Pb zircon and monazite isotopic data of the granitic rocks from Castelo Branco pluton and according to the age uncertainties associated to the method, it could indicate a $310 \mathrm{Ma}$ emplacement for these granitic rocks. This suggests that the granitic rocks from Castelo Branco pluton are contemporaneous (Table 2).

Table 2.-U-Pb zircon and monazite ages of granitic rocks from Castelo Branco pluton (central Portugal)

\begin{tabular}{lcccc}
\hline & $\begin{array}{c}\text { Zircon age (Ma) } \\
(\mathrm{MSWD})\end{array}$ & $\begin{array}{c}\text { Zircon age }(\mathrm{Ma})^{2} \\
{ }^{207} \mathrm{~Pb} /{ }^{206} \mathrm{~Pb}\end{array}$ & $\begin{array}{c}\text { Monazite age }(\mathrm{Ma})^{3} \\
{ }^{207} \mathrm{~Pb} /{ }^{235} \mathrm{U}\end{array}$ & $\begin{array}{c}\text { Zircon }+ \text { monazite age (Ma) }^{4} \\
(\mathrm{MSWD})\end{array}$ \\
\hline GrA & $\begin{array}{c}309.9 \pm 1.1 \mathrm{Ma} \\
(\mathrm{MSWD}=1.11)\end{array}$ & $309.9 \pm 1.0 \mathrm{Ma}$ & $309.5 \pm 0.9 \mathrm{Ma}$ & Not defined \\
\hline GrdB & Not defined & $310.1 \pm 0.8 \mathrm{Ma}$ & $310.6 \pm 1.5 \mathrm{Ma}$ & $\begin{array}{c}307 \pm 28 \mathrm{Ma} \\
(\mathrm{MSWD}=1.20)\end{array}$ \\
\hline GrE & $\begin{array}{c}309.1 \pm 0.6 \\
(\mathrm{MSWD}=0.11)\end{array}$ & $309.7 \pm 0.4 \mathrm{Ma}$ & $309.7 \pm 0.4 \mathrm{Ma}$ & Not defined \\
\hline
\end{tabular}

GrA: muscovite > biotite granite.

GrdB: slightly porphyritic biotite $>$ muscovite granodiorite.

GrE: muscovite > biotite granite.

1 Zircon concordia ages.

$2{ }^{207} \mathrm{~Pb} / 206 \mathrm{~Pb}$ age of concordant zircon crystal.

$3{ }^{207} \mathrm{~Pb} / 235 \mathrm{U}$ age of concordant monazite crystal.

4 Zircon and monazite concordia ages. 


\section{Whole rock $\mathrm{Rb}-\mathrm{Sr}, \mathrm{Sm}-\mathrm{Nd}$ and $\delta^{18} \mathrm{O}$}

The average values of initial ${ }^{87} \mathrm{Sr} /{ }^{86} \mathrm{Sr}$ and $\varepsilon \mathrm{Nd}_{\mathrm{T}}$ isotopic ratios were calculated using the $\mathrm{U}-\mathrm{Pb}$ zircon and monazite age of $310 \mathrm{Ma}$ (Table 3). The isotopic ratios and whole-rock granitic $\delta^{18} \mathrm{O}$ values are characteristic of rocks resulting by crustal anatexis from metasedimentary materials. The muscovite $>$ biotite granite GrA, slightly porphyritic biotite $>$ muscovite granodiorite GrdB and muscovite $>$ biotite granite GrE (Fig. 1) correspond to three distinct pulses of granite magma. The porphyritic biotite $>$ muscovite granodiorite GrdC and biotite-muscovite granite $\mathrm{GrD}$ are the products of in situ fractional crystallization of granodiorite magma GrdB controlled by fractionation of plagioclase, quartz, biotite and ilmenite (Antunes et al., 2008).

The granitic rocks GrA, GrdB and GrE have distinct initial ${ }^{87} \mathrm{Sr} /{ }^{86} \mathrm{Sr}$ ratios, $\varepsilon \mathrm{Nd}_{310}$ and $\delta^{18} \mathrm{O}$ values (Table 3), indicating that they are related to distinct pulses of magma, associated with the heterogeneous Lower Palaeozoic pelitic country rock.

The $\left({ }^{87} \mathrm{Sr} /{ }^{86} \mathrm{Sr}\right)_{310}$ and $\varepsilon \mathrm{Nd}_{310}$ variations on the magmatic sequence between GrdB, GrdC and GrD are small (Table 3 ) and whole-rock $\delta^{18} \mathrm{O}$ values increase from granodiorite GrdB $(12.27 \%$ ) to granite $\operatorname{GrD}(12.75 \%$ ), which can be associated with the fractional crystallization process (e.g., White, 2003).

The Castelo Branco pluton shows an uncommon reverse zoning. The oldest muscovite $>$ biotite GrA intruded the core of the pluton. Granodiorite GrdB magma intruded and originated the biotite>muscovite granodiorite GrdC and biotite-muscovite granite GrD towards the pluton outer zone. Muscovite>biotite granite GrE correspond to another magmatic pulse, which forms some external parts of the pluton.

\section{Conclusions}

1. U-Pb ID-TIMS isotopic zircon and monazite ages are the more precise. However, $\mathrm{U}-\mathrm{Pb}-\mathrm{Th}$ monazite ages obtained by electron microprobe provide similar ages.

2. The granitic rocks GrA, GrdB and GrE, which are related to three distinct magma pulses, have a similar U-Pb ID-TIMS zircon and monazite age of $310 \pm 1 \mathrm{Ma}$.

3. These granitic rocks have distinct values of $\left({ }^{87} \mathrm{Sr} /{ }^{86} \mathrm{Sr}\right)_{310}, \varepsilon \mathrm{Nd}_{310}$ and $\delta^{18} \mathrm{O}$.
Table 3.-Average values of $\left({ }^{87} \mathrm{Sr} /{ }^{86} \mathrm{Sr}\right)_{310}, \varepsilon \mathrm{Nd}_{310}$ and $\delta^{18} \mathrm{O}$ of granitic rocks from Castelo Branco pluton (central Portugal)

\begin{tabular}{lccc}
\hline & $\left({ }^{87} \mathrm{Sr} /{ }^{86} \mathrm{Sr}\right)_{310}$ & $\varepsilon \mathrm{Nd}_{310}$ & $\delta^{18} \mathrm{O}(\% \circ)$ \\
\hline $\mathrm{GrA}$ & 0.7090 & -3.8 & 13.53 \\
$\mathrm{GrdB}$ & 0.7108 & -1.7 & 12.27 \\
$\mathrm{GrdC}$ & 0.7104 & -0.8 & 12.50 \\
$\mathrm{GrD}$ & 0.7086 & -2.8 & 12.75 \\
$\mathrm{GrE}$ & 0.7120 & -3.0 & 12.91 \\
\hline
\end{tabular}

GrA: muscovite > biotite granite.

GrdB: slightly porphyritic biotite $>$ muscovite granodiorite. GrdC: porphyritic biotite > muscovite granodiorite.

GrD: biotite-muscovite granite.

GrE: muscovite>biotite granite.

4. The granitic rocks $\mathrm{GrdB}, \mathrm{GrdC}$ and $\mathrm{GrD}$ are related by a fractional crystallization process and present small variations in the $\left({ }^{87} \mathrm{Sr} /{ }^{86} \mathrm{Sr}\right)_{310}, \varepsilon \mathrm{Nd}_{310}$ and $\delta^{18} \mathrm{O}$ isotopic values.

5. Castelo Branco pluton shows an uncommon reverse zoning and the first one known in Portugal.

\section{ACKNOWLEDGMENTS}

Thanks are due to Prof. Fernando Corfu for the facilities at the Geosciences Department of the University of Oslo (Norway); to Prof. A.C. Fernandèz for the facilities at Laboratório de Geologia e Geocronologia of the University of Oviedo, Spain; Prof. F. Bea and Prof. P. Montero for the Rb-Sr and Sm-Nd isotopic data obtained at the Centro de Instrumentación Científica of the University of Granada, Spain; Dr. Jean-Luc Devidal for the facilities to obtain U-Pb-Th data on monazites at the Laboratoire Magmas et Volcans of the University of Blaise Pascal, Clermont-Ferrand, France; Prof. F.J. Longstaffe for the oxygen isotope analyses obtained at the Department of Earth Sciences, University of Western Ontario, Canada. Funding was provided to I.M.H.R. Antunes by the SFRH/BD/2885/2000 grant from Fundação para a Ciência e a Tecnologia. This research was carried out under the Geoscience Centre programme, University of Coimbra, Portugal.

\section{References}

Antunes, I.M.H.R.; Neiva, A.M.R.; Silva, M.M.V.G. \& Corfu, F. (2008). Geochemistry of S-type granitic rocks from the reversely zoned Branco pluton (central Portugal). Lithos, 103: 445-465. doi:10.1016/j.lithos.2007.10.003

Azevedo, M.R.; Valle Aguado, B.; Nolan, J.; Martins, M. \& Medina, J. (2005). Origin and emplacement of synorogenic Variscan granitoids in Iberia the Beiras massif. In: The southern Variscan Belt. (Carosi R.; Dias, R.; Lacopini, D. \& Rosenbaum G., eds.), Journal of the Virtual Explorer, Electronic Edition, 19, Paper 7.

Corfu, F. (2004). U-Pb geochronology of the Lekres group: an exotic Early Caledonian metasedimentary 
assemblage stranded on Lofoten basement, northern Norway. Journal of the Geological Society of London, 161: 619-627. doi:10.1144/0016-764903-066

Dias, G.; Simões, P.P.; Ferreira, N. \& Leterrier, J. (2002). Mantle and Crustal Sources in the Genesis of LateHercynian Granitoids (NW Portugal): Geochemical and Sr-Nd Isotopic Constraints. Gondwana Research, 5: 287-305. doi:10.1016/S1342-937X(05)70724-3

Ferreira, N.; Iglésias, M.; Noronha, F.; Pereira, E.; Ribeiro, A. \& Ribeiro M.L. (1987). Granitóides da zona Centro-Ibérica e seu enquadramento geodinâmico. In: Geologia de los granitoides y rocas asociadas del Macizo Hespérico, Libro Homenaje a L.C.G. Figueirola (Bea, F.; Carmina, A.; Gonzalo, J.C.; Plaza, M.L. \& Rodrigues, J.M.L., eds.), Editorial Rueda, Madrid, 37-53.

Krogh, T.E. (1973). A low contamination method for hydrothermal decomposition of zircon and extraction of $\mathrm{U}$ and $\mathrm{Pb}$ for isotopic age determination. Geochimica et Cosmochimica Acta, 37: 485-494. doi:10.1016/0016-7037(73)90213-5

Martínez Catalán, J.R.M.; Martínez Poyatos, D. \& Bea, F. (2004). Zona Centroibérica: Introducción. In: Geología de España (Vera, J.A., ed.). Instituto Geológico y Minero de España (SGE-IGME), Madrid, 68-69.
Montel, J.M.; Foret, S.; Veschambre, M.; Nicollet, C. \& Provost, A. (1996). Electron microprobe dating of monazite. Chemical Geology, 131: 37-53. doi:10.1016/00092541(96)00024-1

Montero, P. \& Bea, F. (1998). Accurate determination of ${ }^{87} \mathrm{Rb} /{ }^{86} \mathrm{Sr}$ and ${ }^{147} \mathrm{Sm} /{ }^{144} \mathrm{Nd}$ by inductively coupled plasma mass spectrometry in isotope geoscience: an alternative to isotope dilution analysis. Analytica Chimica Acta, 358: 227-233. doi:10.1016/S0003-2670(97)00599-0

Neiva, A.M.R. \& Gomes, M.E.P. (2001). Diferentes tipos de granitos e seus processos petrogenéticos: granitos hercínicos portugueses. Memórias da Academia das Ciências de Lisboa, 39: 53-95.

Rollinson, H. (ed.) (1993). Using Geochemical Data: Evalution, Presentation and Interpretation. Longman, UK, 352 pp.

White, J. (2003). High temperature applications II: Oxygen isotopes as an indicator of assimilation. University of Cornell, Earth \& Atmospheric Sciences 656, Isotope Geochemistry Lectures, 30: 227-231.

Recibido el 26 de noviembre de 2009 Aceptado el 4 de febrero de 2010 Publicado online el 28 de abril de 2010 